the cymes of the maple-leaved arrow-wood (Viburnum acerifolia) just as they are going out of bloom. The fruit of this does not ripen till October, and some larva lives in the fleshy substance in which the thin, flat coriaceous seed is immersed, which is probably that of this Apion, though not yet so proven. This is one of the largest species of the genus, and when beaten into the umbrella behaves and looks so much like the worthless Anthonomus quatdrigibbus, that till the past season it was always rejected.

\title{
DESCRIPTION OF THE PREPARATORY STAGES OF ARGYNNIS HESPERIS, EDW.
}

BY W. H. EDWARDS, COALBURGE, W. VA.

EGG.-Conoidal, round-topped, nearly as broad at base as high, the top depressed; marked by about I 9 thin, elevated, vertical ribs, one half running from base to summit, the others but four fifths or more the distance; the spaces between crossed by many low horizontal ridges; the micropyle surrounded by two or three circles of very fine depressions, outside of which are rows of very large four or five-sided depressed cells; color yellow-green. Duration of this stage about ten days.

Young LaRva.--Length .06 inch; cylindrical, thickest in middle; color yellow-green; marked as in the allied species by rows of flattened tuberculous brown spots, each of which gives one or two long, tapering hairs; on dorsum of 2 a dark oval patch with a row of hairs in front, turned forward, and a shorter row behind; head obovoid, black, with many long hairs. The larva hibernates directly from the egg.

After First Moult: Length .I inch; color green, mottled with brown over dorsum; the under side pale green; the spines in number and position as at maturity, and as in the genus, small at base, tapering little, wholly black, beset with many short black bristles; head obovoid, black, with black hairs. Duration of this stage eight days, in April and May.

After Second Moult: Length . I5 inch; color brown and gray; a double indistinct gray dorsal stripe, and a similar one between dorsal and upper lateral spines; the spinas black; those of the middle row have the bases on outer side pale yellow, of the lower row the bases are wholly pale yellow; head as before. Duration of this stage eight days, in May. 
After Third Moult: Length .28 inch; color black and dark gray, the sides mottled; the double dorsal stripe more definite than before; the spines as before; head same also. To next moult four days, in May.

After Fourth Moult: Length .44 inch; color black and gray; the dorsal stripe now solid, dark gray; the spines black to bases except those of lower row, and on 3 and 4 of middle row, all which have yolk-yellow at base and half way up the stems; all bristles black; head brown-black over the front with many black hairs, long and short, the back brownishyellow. To next moult eight days, in May.

After Fifth Moult: Length .7 inch; in about eight days was fully grown.

Mature Larva,-Length I. 2 to I. 4 inch; slender, somewhat thickened in middle, the segments well rounded; color wholly velvet-black or brown-black (no gray dorsal stripe as before last moult); three rows of spines on either side, as in the genus, all of them yellow nearly to tip, the rest black ; feet black, pro-legs brown-yellow; head sub.cordate, the vertices rounded, dull brown in front, dull yellow at back. From fifth moult to pupation $\mathrm{I}_{4}$ days.

Chrysalis.-Length .9 inch; breadth across mesonotum.26, across abdomen .23 inch; like Atlantis in shape, but stouter; color dark brown over head and wing cases; so also on the front of each abdominal segment, in serrations, the rest yellow-brown. Duration of this stage ten days, in June.

Hesperis flies in Colorado, Utah and Montana. Mr. Bruce writes me of its habits thus: "Hesperis is by far the most abundant species of the genus along the canons and water courses of the eastern or front range of the Rocky Mtns., in Colorado, at from 6,500 to 8,000 feet elevation. It is very active and restless, and difficult of capture except when on flowers. They are very partial to the bloom of Clematis, and I have frequently taken several at one sweep of the net on this plant; later in the season, on the tall Sunflower. The wild Bergamot and Horse-mint are much frequented by them. They are also fond of alighting on the ground in damp places, especially, late in the summer, when they are worn. I have taken them in Clear Creek and Platte canous from June $\mathbf{I}$ 6th till end of August. Hesperis is a very pugnacious insect, and will circle round and boldly flap the Lycaenas and Theclas off the blossoms. I was amused one day, on the South Platte, with watching a male Hesperis 
It has been determined by the Council of the Entomological Society of Ontario to make their collection a representative one of Canadian Entomology, and thus enable it to be of permanent use for reference and comparison.

This is the more desirable as owing to the Collection having been exhibited in England and the United States on various International occasions, many specimens have lost their color and freshness.

Mr. J. Alston Moffatt, of Hamilton, Ont, has kindly consented to revise and re-arrange the Collection.

Printed lists will be published from time to time of desiderata required to fill up and replace the various sections.

We appeal to our members and friends to help the Society in this useful work, and to send what specimens they can procure of the insects required

Insects used by the Society in this way will be labelled in the Collection with the name and address of the donor.

The following list of Lepidoptera has been prepared, showing what are the more immediate wants in this class.

It is not expected that all these will be obtained from present Collections, but members might bear in mind what is wanted, and endeavor to make special captures during the next and following seasons.

All specimens should be securely packed and sent by express at the cost of the Society, directed to Mr. W. E. Saunders, London, Ont.

April, I 888.

\begin{tabular}{|c|c|c|}
\hline \multicolumn{3}{|c|}{ LEPIDOPTERA-LIST A. } \\
\hline $\begin{array}{l}\text { Papilio } \\
\text { marcellus, Cram. } \\
\text { cresphontes, Crim. } \\
\text { Phyciodes } \\
\text { nycteis, Walker. } \\
\text { tharos, Cran. } \\
\text { tharos var. marcia. } \\
\text { Limenitis } \\
\text { ursula, Fab. } \\
\text { arthemis var. prosernina, } \\
\text { Debis } \\
\text { Portlandia, Fab. } \\
\text { Neonympha } \\
\text { canthus, } B d,-L e c \text {. }\end{array}$ & $\begin{array}{l}\text { Chionobas } \\
\text { juita, Hul. } \\
\text { Satyrus } \\
\text { nephele, Kirby. } \\
\text { Thecla } \\
\text { calanus, Hudb. } \\
\text { Ontario, Edtw. } \\
\text { hyperici, Boisd s Lec. } \\
\text { Edwardsii, Saunders. } \\
\text { falacer, Godt. } \\
\text { niphon, Boisd et Lec. } \\
\text { strigosa, Harr. } \\
\text { humuli, Harr. } \\
\text { titus, Fab. } \\
\text { Feniseca } \\
\text { tarquinius, Fab. }\end{array}$ & $\begin{array}{l}\text { Lycaena } \\
\text { comyntas, Godt. } \\
\text { neglecta, Edtiards. } \\
\text { violacea, Edw. } \\
\text { Carterocephalus } \\
\text { maudan, Edre. } \\
\text { Ancyloxypha } \\
\text { numitor, Fab. } \\
\text { Pamphila } \\
\text { zabulon var. pocahontas, } \\
\text { Scizd. } \\
\text { cernes, Bd.-Lcc. } \\
\text { Pyrgus } \\
\text { centaurex, Ramb. } \\
\text { Nisoniades } \\
\text { persius, Scudder. }\end{array}$ \\
\hline
\end{tabular}


Nisoniades

brizo, Boisd. st Lec. juvenalis, Smith.

Amphion nessus, Cram.

Thyreus Abbotii, Swains.

Philampelus pandorus, Hubn achemon, Drury.

Ampelophaga versicolor, Ham.

Paonias myops, $A b b$. \& $S \mathrm{sm}$. Sphinx kalmiae, Snith.

Ellema bombycoides, Walk. Alypia MacCullochii, Kirb.

Scepsis fulvicollis, Hubn.

Lycomorpha pholus, Drury.

Clemensia albata, Pack.

Hypoprepia

fucosa, $H u$ m fucosa, var. miniata,

Crocota ferruginosa. $W_{c i l h}$. quinaria, $G r$.

Treatii, Grote rubicundaria, $H u b n$.

Utetheisa bella, Linn.

Callimorpha clymene, Esp.

Platarctia parthenos, Harr.

Arctia

nais, Dror.

decorata, Saunders. celia, Saunders. virguncula, Kirb. arge. Drury,

Phragnatobia rubricosa, Harris.

Euchates egle, Drur.

Halesidota tesselaris, $S m$. $A b$. caryae, Harris.

Euclea

quercita, $H . S$. ferruginea, Pack.
Parorgyia

Clintonii, $G$. \& $R$. parallela, Pack.

Limacodes biguttatus, Fack.

Empretia stimulea, Clem.

Phobetron pithecium, $A b b$. \& $5 \mathrm{~m}$.

Tortricidia testacea, Pack.

Ichthyura

inversa, Pack. albosigma, Fitch.

Datana

ministra, Drury.

Nadata gibbosa, Waiker.

Prionia bilineata, Pack.

Actias luna, Limn.

Platypteryx genicula, Grote. arcuata, Walk.

Dryopteris rosea, Walh

Eacles imperialis, Irury. Kithy. Anisota

stigma, Fabr. senatoria, $A$. \& $S$. virginiensis, Drury.

Dryocampa rubicunda, Fab.

Clisiocampa disstria, Hubn.

Microcoelia diphteroides, Guen. obliterata, Grote.

Bryophila lepidula, $G r$.

Chytorix palliatricula, Guen.

Dipthera fallax, $H . S$.

Ccelodasys unicornis, $A, \mathcal{O}^{\circ} S$

Hepialus thule, Strk.

Apatela dissecta, $G$. \& $R$. grisea, Walk.

Agrotis Normaniana, Grote.

Mamestra, distincta, Grote.
Hadena

mactata, Guen fractilinea, Grote.

Oligia versicolor, $G r$.

Anytus sculptus, $G r$.

Oncocnemis occata, Grote.

Prodenia flavimedia, Hàrvey.

Gortyna, sera, $G \& R$ nictitans, Borkh. immanis, Guen. cataphracia, Grote. nebris, Guen. rutila, Guen.

Achatodes

$$
\text { zeae, Hary. }
$$

Arzama

obliquata, $G$. \& $R$.

Heliophila

pallens, Linn.

Harveyi, Grote.

phragmitidicula, Grote:

lapidaria, Grote.

adonea, Groto

commoides, Guen. unipuncta, Haze. pseudargyria, Guen.

Ufeus satyricus, Grote.

Caradrina multifera, Walk.

Pyrophila pyramidoides, Gucn.

Tæniocampa furfurata, $G r$.

Parastichtis gentilis, Grote.

Ipimorpha pleonectusa, Grote

Nolaphana malana, Fitch.

Aletia argillacea, Hubn.

Marasmalus histrio, Grote

Calpe Canadensis, Beth.

Plusia

contexta, Grote.

Putnami, Grote.

biloba, Steph viridisignala, Grote. mortuorum, Guen. 
Plusia ampla, Walk.

Lygrantboecia rivulosa, Guen.

Anthœcia arcifera, Gucn. Spraguei, Gr.

Anarta cordigera, Thunb.

Tarache candefacta, Huobz erastrioides, Guen.

Eustrotia albidula, Guen. nauscosula, Guen.

Celiptera frustulum, Guen.

Phoberia atomaris, Hubn Remigia latipes, Guen.

Parthenos nubilis, $H u b n$.

Catocala

unijuga, Walk

faustina, Strecker.

semirelicta, Grote.

briseis, Edw.

parta, Guen.

coccinata, Grote.

ultronia, Hubon.

concumbens, Walk. amatrix, $F u b n$.

cara, Guen.

ilia, Cram.

neogama, $A b b$.

subnata, Grote.

Meskej, Grote.

antinympha, Hubn

palaeogama, var. pha-

palaeogama. Guent.

habilis, Grote.

Clintonii, Grote.

fratercula, $G$. \& $R$.

polygama, Guen.

crataegi, Saund.

amica, $H u b n$.

ilia, var uxor, Guen.

innubens, Guen.

cerogama, Guen.

serena, Eazw.

similis, Edre.

grynea, Cram.

Panapoda

rufimargo, Hubn.
Erebus

odora, Linn.

Homoptera

lunata, Drury.

Saundersii, Beth.

calycanthata, $A b b$. \& . Sm

albofasciata, Beth.

edusa. Prury.

duplicala, Beth.

benesignata, Haracy.

Ypsia

undularis, Drury.

umbripennis, Grote.

Zale horrida, Hubn

Spargaloma sexpunctata, Grote

Pangrapta. decoralis, Huon.

Pseudaglossa lubricalis, Geyer.

Epizeuxis aemula, Hubn. americalis, Guen.

Megachyta lituralis, $F u b n$

Litognatha nubilifascia, Grote.

Chytolita morbidalis, Guen.

Pityolita pedipilalis, Guen.

Zanclognatha laevigata, Grote. ochreipennis, Grote. cruralis, Guen. marcidilinea, Grote.

Philometra longilabris. Grote. serraticornis, Grote. Palthis augulalis, $H u b n$.

Renia asopialis, Guen.

Belfragei, Grote.

Bleptina caradrinalis, Guen.

Hypena baltimoralis, Guen. scutellaris. $G r$ manalis, Walk. abalienalis, Walk. achatinalis, Zell. profecta, $G r$ deceptalis, Walk. perangulalis. Harz vellifera, $G r$
Hypena

evanidalis, Rob, scabra, Fabr.

Choerodes clemitaria, $A . S$ transversala, Drary

Metanema
quercivoraria, Guen

Ennomos alniaria, Linn

Eudalimia subsignaria, Hubn.

Endropia

obtusaria, Hubn

effectaria, Walk.

bilinearia, Pack armataria, $H . S$

Therina

fervidaria, Hubn. endropiaria, $G$. \& $R$ bibularia, $G, \& R$.

Metrocampa margaritata, Linn.

Anagoga pulveraria, Linn.

Sicya macularia, Harris.

Plagodis

rosaria, $G$. $R$.

phlogosaria, Guen. alcoolaria, Guen.

Hyperetis amicaria, $H . S$.

Aplodes mimosaria, Guen. Synchlora rubivora, Riley.

Annemoria unitaria, Pack.

Nemoria subcroceata, Walk:

Eucrost is chloroleucaria, Guen:

Acidalia nivosata, Guen. quadrilineata, Pack.

Eudeilinia herminiata, Guen. Aspilates Lintneriaria, Pack.

Nematocampa filamentaria, $H . \cdot S$.

Thamnonoma subcessaria, Walk, argillacearia, Pack.

Eufitchia ribearia, Fitch. 
Caripeta angustiorata, Walk.

Hibernia tiliaria, Harris.

Anisopteryx vernata, Peck. pometaria, Harr Cymatophora humaria, Guen.

Tephrosia canadaria, Guen. anticaria, Walk.

Eubyja quernaria, $A$. de $S$.

Rheumaptera ruficillata, Guen. basaliata, Walk. lacustrata, Gucn. hastata, Lim.

Petrophora diversilineata, $H u b n$. hersiliata, Gucn.

Epirrita perlineata, Pack. cambricaria, Curtis. dilutata, Borkh.

Asopia

farinaiis. Iinn squameali:, Grote. costalis, Fabr. olinalis, Guen. devialis, Grote.

Botis

octomaculata, Linn. generosa, $G$. $d R$. insequalis, Guen. marculenta. $G$. $d R$. signatalis, Walk.
Botis

niveicilialis, Grote plectilis, $G, d R$. gentilis, Grote magistralis, Grote. terrealis, Treits. submedialis, Grote. marculenta, $G$, d $R$. subdentalis, Grote. citrina, $G . \& R$ sumptussalis, Walk. Harveyana, $G r$.

Mesographe stramentalis, Hubn.

Blepharomastix ranalis, $G u n$.

Cataclysta fulicalis, Cleme.

Tetralopha asperatella, Clem.

Phycis indiginella, Zell.

Dakruma convolutella, Hubn.

Argyria nivalis, Drury.

Crambus

Leachellus, Zinck. agitatellus var. albocla
vellus, $S c h t$

albellus, Clem. bipunctellus, Zell. topiarius, Zell

Schoenobius longirostrellus, Clem. Cacœeia purpurana, Clemt. cerasivorana, Fitch.
Loxolænia afflictana, IValk.

Ptycholoma persicana, Fitch melaleucana, Walk.

Pandemis limitata, Robs.

Enectra puritana, Robs.

Cenopis Pettitana, Roos.

Dichelia sulfureana, Clem.

Amphisa discopunctana, Clem. Capua furcatana, Walk.

Eccopsis permundana, Clem.

Penthina nimbatana, Clem.

Sericoris coruscana, Clem.

Pædisca campestrana, $Z \mathrm{ell}$.

Scudderiana, Clem.

Semasia formosana, Clem.

Timetocera ocellana, Schiff.

Phoxopteris nubeculana, Clem. discigerana, Walk spireæfoliana, Clem.

Grapholitha interstinctana, Clem. 
endeavoring to drive a Zygaenid moth (Anatolmis Grotei) off the blossoms of a large species of Senecio. The moth, which is a sluggish creature at all times, would not fly, but slowly backed round the corymbose head of flowers, occasionally lifting its front legs in feeble protest. Hesperis followed it, flapping its wings and clawing at it like a cat, till the persecuted moth at last escaped by slipping over the petals, and hanging on the under side. It is probably owing to this restless and quarrelsome disposition that individuals are so soon worn and broken. They vary much in size and in the color of the spots on under side, some being of a deep buff, others a dead white, and others with a trace of frosted silver. I have taken Hesperis just below the timber line, but it is not common at such elevations, nor below 6,500 feet in Colorado."

Mr. Bruce sent me eggs of this species from Denver, Colorado, which I received gth July, 1886 , and a second lot three days later. The eggs hatched at ten days, and after eating the shells, the larvæ went into lethargy. I sent them soon after to Clifton Springs, N. Y., to go in a cold room there, and they were returned $2 \mathrm{Ist}$ March, I887, nearly all alive. But they came unexpectedly, and a month too soon, and before I could force a plant of violet for them nearly all had died. Of the few survivors, one passed Ist moult 2oth April, the second 3 rd May, the third I r th May, the fourth ${ }_{5} 5_{\text {th, the fifth }} 3_{3}$ rd. This larva pupated 6 th June, and the imago came out I 6 th June. Another pupated irth June, but died before imago. The habits of the larvæ in confinement are similar to those of Atlantis. The butterfly is figured in Vol. r, Butterflies of N. America.

\section{SOME NEW NOCTUIi)A:}

BY C. H. FRENCH, CARBONDALE, ILL.

Cucullic Hartmanni, n sp.

Expanse 1.75 inches, length of body .75 inch. General color of fore wings pale gray, so suffused in places with dark gray as to give the wings a moderately dark gray cast, but not so dark as $C$. intermedia, Spey. Lines black, basal half line only indicated on the costa. T. a line double; the inner part almost imperceptible ; strongly dentate, from its origin projecting obliquely outward to a strong tooth on the fold in the discal cell, 